Digitalizacja archiwalnych numerów czasopisma naukowego Analecta Cracoviensia 1-24 (1969-1992) i ich publikacja w otwartym dostępie - zadanie finansowane w ramach umowy 672/P-DUN/2017 ze środków Ministra Nauki i Szkolnictwa Wyższego przeznaczonych na działalność upowszechniającą naukę

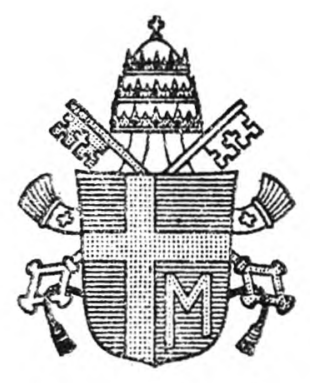

\title{
LIST APOSTOLSKI
}

DO CZCIGODNYCH BRACI

STEFANA KARDYNAEA WYSZYNSKIEGO

ARCYBISKUPA-METROPOLITY GNIEZNIENSKIEGO I WARSZAWSKIEGO PRYMASA POLSKI

FRANCISZKA MACHARSKIEGO

ARCYBISKUPA METROPOLITY KRAKOWSKIEGO

WSZYSTKICH BISKUPOW POLSKICH

I CALEGO KOSCIOLA W POLSCE

\section{Z OKAZJI JUBILEUSZU DZIEWIECSETNEJ ROCZNICY SMIERCI SWIĘTEGO STANISEAWA, BISKUPA I MĘCZENNIKA}

I. Swiadectwo męczeńskie tych, którzy za wiarę i chrześcijańskie zasady ̇̇ycia przyjęli cierpienie $i$ męki oraz odważnie ponieśli śmierć od poczatku, przez całe wieki dodawały Kościołowi duchowej siły $i$ mocy. Słusznie więc mówi św. Augustyn: „Jakby nasieniem krwi wypetniona jest męczennikami ziemia, i $z$ tego nasienia wyrosto żniwo Kościoła. Bardziej obwieszczaja. Chrystusa zmarli niż żywi. Dziś Go obwieszczaja $i$ dziś głosza: milczy język, ale rozbrzmiewaja czyny" (Serm. 286, 4; PL 38, 1298). Istnieja chyba szczególne racje, by słowa te obecnie odnieść do Kościoła $w$ Polsce. Przecież także $i$ On wyróst $z$ krwi męczenników, wśród których, naczelne miejsce zajmuje św. Stanisław. Jego życie i śmierć chwalebna przemawiaja ustawicznie. 
W roku, w którym Kościót w Polsce obchodzi uroczyście dziewięćsetna rocznicę męczeńskiej śmierci św. Stanisława, biskupa krakowskiego, nie może zabraknqć Biskupa Rzymu i Następcy św. Piotra. Nazbyt doniosty to jubileusz, nazbyt zwiazany $z$ dziejami Kościoła i Narodu Polskiego, który przez z góra tysiac lat swoich dziejów zwiazał się $z$ tym Kościołem w sposób szczególnie głęboki. Nie może zabrakną́ tego głosu zwłaszcza $w$ tym momencie, kiedy na stolicę św. Piotra tajemnym zrzadzeniem Bożej Opatrzności został wezwany papież, który sam do niedawna jeszcze był następca św. Stanisława na stolicy biskupiej w Krakowie.

Przedziwna to zaiste chwila, kiedy wypada mi pisać $w$ zwiazku $z$ jubileuszem św. Stanisława stowa, o których napisanie sam uprzednio prositem wielkiego mojego Poprzednika Papieża Pawła VI, a $z$ kolei jego bezpośredniego Następce Jana Pawła I, który zaledwie przez trzydzieści trzy dni sprawował posługe papieska. Dzisiaj czynię zadość nie tylko temu, o co jako ówczesny arcybiskup krakowski prositem obu moich Poprzedników na Stolicy św. Piotra, ale czynię też zadość szczególnej potrzebie własnego serca. Któż bowiem mógł oczekiwać, że właśnie mnie wypadnie $w$ przededniu jubileuszu św. Stanisława opuścić jego stolice biskupia w Krakowie $i-z$ woli kardynałów zebranych na konklawe przejść do Rzymu? Któż mógł oczekiwać, że wielkie dni tego jubileuszu wypadnie mi obchodzić nie $w$ charakterze gospodarza uroczystości, ale $w$ charakterze gościa, przybywając do ziemi moich przodków jako pierwszy papież - Polak i zarazem jako pierwszy w dziejach Kościoła papież nawiedzajacy te ziemię?

II. Uroczystość św. Stanisława od wieków zwiazana jest w kalendarzu liturgicznym Kościoła w Polsce $z$ dniem 8 maja. Zewnętrzna zaś uroczystość przenosi się $w$ Krakowie na najbliższa po 8 maja niedzielę. W tym też dniu wyrusza $z$ katedry Wawelskiej procesja do kościoła św. Michała na Skaice - tam, gdzie wedle tradycji biskup Stanisław ze Szczepanowa ponióst śmierć $z$ rak króla Bolesława Śmiałego $w$ czasie sprawowania Eucharystycznej Ofiary.

W roku bieżacym tę gtównq - a zarazem jubileuszowa - uroczystość św. Stanisława postanowiliśmy przenieść nie na najbliższa niedzielę, ale na niedziele Zesłania Ducha Świętego oraz Trójcy Przenajświętszej. Potężna jest wymowa tego dnia, w którym Kościót przypomina sobie swoje narodziny w jerozolimskim wieczerniku. To stamtad wyszli Apostotowie, którzy zebrani byli na modlitwie z Maryja, Matka Chrystusa (por. Dz 1, 14) - wyszli petni męstwa, które zstapiło do ich serc jako szczególny dar Ducha Swiętego. Stamtąd wyszli - a potem wyruszyli w świat, aby wypetnić Chrystusowe zlecenie: „Idźcie więc i nauczajcie wszystkie narody, udzielajac im chrztu $w$ imię Ojca $i$ Syna, i Ducha 
Swiętego. Uczcie je zachowywać wszystko, co wam przykazalem" (Mt 28, 19-20).

$\mathrm{Z}$ wieczernika Zielonych Swiat wyszli Apostotowie. $Z$ niego też pokolenie po pokoleniu - wyruszaja ich następcy. $Z$ niego wyruszyt $w$ swoim pokoleniu Stanistaw ze Szczepanowa, niosac w sercu ten dar męstwa, aby świadczyć o prawdzie Ewangelii aż do przelania krwi. Owo pokolenie odległe od nas dziewięć stuleci jest pokoleniem naszych przodków, którzy tak jak Stanistaw, ich biskup na krakowskiej stolicy, stanowia kość $z$ kości i krew z krwi naszej. Czas jego pasterzowania by krótki: od 1072 do 1079 roku - siedem lat. Owoc zaś itrwa do dzisiaj. Spetnito się na nim słowo Chrystusowe wypowiedziane do Apostołów, aby szli i owoc przynosili, $i$ aby owoc ich trwat (por. $J$ 15, 16).

III. Jest więc pełna głębokiej wymowy ta tegoroczna uroczystość św. Stanisława, która po dziewięciu wiekach od Jego śmierci przenosi nas do wieczernika Zielonych Swiąt. Stamtąd wszakże wyruszyli ci wszyscy, którzy wedle słów Chrystusa poszli na cały świat, nauczając wszystkie narody, chrzczqc je w imię Ojca i Syna i Ducha Świętego (por. Mt 28, 1920). Naród polski został ochrzczony w imię Trójcy Przenajświętszej w $966 r$. Niedawno minęło tysiąc lat od tej daty, która oznacza równocześnie początek dziejów Kościoła $w$ Polsce oraz początek dziejów Narodu.

Jakize potężna jest moc Chrztu - tego Sakramentu, który zanurza nas w śmierć Chrystusa (por. Kol 2, 12), aby dać nam przez to udziai w Jego zmartwychwstaniu: 'w tym Życiu, które Syn Boży, stając 'się człowiekiem, uczynit życiem naszych dusz. Właśnie o początku tego życia stanowi $w$ nas Chrzest $w$ imię Trójcy Przenajświętszej - Chrzest, który synom ludzkim daje „,moc, aby się stali dziećmi Bożymi” $(J 1,12)$ w Duchu Swiętym.

Tysiąclecie Chrztu, 'które $w$ roku 1966 było obchodzone na ziemi polskiej jako całoroczne uwielbienie Przenajświętszej Trójcy, ogarnia soba również obecny jubileusz św. Stanistawa. Wszakże najpetniejszym owocem tego Sakramentu, który każdego człowieka w sposób szczególny poświęca Bogu (Sobór Wat. II, Konst. dogm. o Kościele, Lumen gentium, 44), sq właśnie święci, ci, którzy przez swoje życie i śmierć stali się wiecznỳm darem dla Boga (por. III Modlitwa Eucharystyczna).

Kiedy więc $z$ kolei $w$ uroczystości Trójcy Przenajświętszej Roku Pańskiego 1979 będziemy uroczyście obchodzić pamiątkę męczeńskiej śmierci św. Stanisława, wspomnijmy na ten Chrzest wimię Trójcy Przenajświętszej, $z$ którego wyróst pierwszy $w$ Narodzie polskim łdojrzały owoc świętości. Tak bardzo oczekiwany przez cały Naród, który w tym Swiętym Rodaku uznał $z$ wdzięcznościa owoc nowego życia, jakie stało się jego udziałem od chwili, kiedy Polska przyjęta Chrzest.

Dlatego też dziewięćsetna rocznicę męczeńskiej śmierci św. Stanisła- 
wa wpisujemy ze szczególna czcia w tysiąclecie Chrztu przyjętego przez naszych Praojców w imię Ojca i Syna i Ducha S'więtego. Aby zaś dać wyraz tej czci, niech odtad zgodnie $z$ życzeniem Episkopatu Polski wspomnienie św. Stanisława $w$ kalendarzu liturgicznym Kościoła Powszechnego posiada charakter wspomnienia obowiazkowego (memoria obligatoria).

IV. Głębokie korzenie czci, jaka odbiera na ziemi polskiej św. Stanisław od dziewięciu stuleci.

Przyczynita się do tej czci kanonizacja, dokonana w dniu 8 września 1253 r. przez papieża Innocentego IV, mojego Poprzednika, w Asyżu przy grobie św. Franciszka. Głębokie sa korzenie tej czci. Sięgaja w całe prawie dzieje Kościoła w Polsce, odzwierciedlaja się w życiu Narodu, towarzysza jego losom. Swiadcza o czci św. Stanistawa nie tylko doroczne uroczystości, ale też liczne wezwania diecezji $w$ Polsce oraz kościołów i parafii $w$ Polsce, a także i poza Polska. Wszędzie tam, gdzie trafili synowie polskiej ziemi, przynosili z soba tę część wielkiego Patrona. Od wielu stuleci był św. Stanisław głównym Patronem Polski. Patronat ten $z$ mocy postanowienia papieża Jana XXIII, mojego Poprzednika - sprawuje wspólnie z Matka Boża, Królowa Polski oraz ze św. Wojciechem. I dlatego też $w$ roku bieżacym, obchodząc dziewięćsetna rocznice śmierci św. Stanisława, wią̇emy te uroczystość nie tylko $z$ Krakowem, ale też $z$ Gnieznem i Jasna Góra. Przez całe już prawie tysiaclecie obok św. Stanisława z Krakowa postępuje św. Wojciech, którego umęczone ciało spoczęto za czasów Bolesława Chrobrego w Gnieźnie. Obaj zaś Swięci: Stanisław i,Wojciech patronuja Ojczyźnie przy boku Maryi, Królowej i Matki Kościoła.

Otacza się czcia miejsca, z którymi związane było życie $i$ śmierć św. Stanisława. Szczególna cześć odbiera Swięty w krakowskiej katedrze na Wawelu, gdzie znajduje się Jego grób i w kościele św. Michała na Skałce oraz $w$ rodzinnym szczepanowie, na terenie dzisiejszej diecezji tarnowskiej, gdzie przyszedł na świat. Otacza się czcia relikwie, a zwłaszcza relikwię głowy Męczennika, która do dzisiaj wykazuje ślady śmiercionośnych ciosów, jakie otrzymała przed dziewięciuset laty. Właśnie przy tej relikwii skupiaja się co roku mieszkańcy królewskiego miasta oraz pielgrzymi z całej Polski, aby w uroczystej procesji przenieść ja przez ulice Krakowa. W tej samej procesji postępowali $w$ dawnych wiekach królowie polscy, następcy Bolesława Smiałego, który świętemu Stanisławowi zadał w 1079 r. ów śmiertelny cios, a jak głosi tradycja, zakończył życie pojednany $z$ Bogiem poza Krajem.

Czyż fakt ten nie posiada szczególnej wymowy? Czyż nie świadczy o tym, że św. Stanisław stał się na długie wieki rzecznikiem pojednania $z$ Bogiem wszystkich swoich rodaków, zarówno sprawujących władzę, jak 
poddanych? Czyż nie mówi o tej szczególnej duchowej jedności, która przez Jego śmierć męczeńska stała sie ich udziałem $i$ jest nim nadal? Taka bowiem jest moc śmierci, która przez tajemnice Chrztu wzrosła gięboko $w$ zmartwychwstanie Chrystusa. W Jego prawde i miłość. A, ,nie ma większej miłości od tej, gdy lktoś życie swoje oddaje za przyjaciót swoich" $(J$ 15, 13).

V. „Stanisław, Patron Polaków” - z jakimże przejęciem, z jakim wzruszeniem wypada wypowiedzieć te słowa papieżowi, który przez tyle lat swego życia i posługiwania biskupiego zwiqzat sie tak blisko $z$ owym patronatem, $z$ cała stanisławowa tradycja; również i $z$ tymi dociekaniami, które na przestrzeni obecnego, a także i poprzedniego już stulecia nie przestaja zajmować umysłów na temat wydarzeń $i$ okoliczności, jakie przed dziewięciuset laty złożyły się na caty historyczny fakt św. Stanistawa. Juz to samo wskazuje, jak fakt ten i postać nie przestaje zawierać $w$ sobie treści, doświadczeń i prawd, stale żywych, stale ważnych dla $\dot{z} y-$ cia człowieka, narodu, iKościoła.

Biorac więc za podstawe te szczególna żywotność postaci św. Stanisława, Patrona Polaków, wypada nam $w$ dziewięćsetna rocznice tego lswiadectwa, jakie złożyz przez swoje życie i śmierć, przedstawiać Bogu $w$ Trójcy Przenajświętszej Jedynemu za pośrednictwem Matki Chrystusa $i$ Kościoła to wszystko, co stanowiło i nadal stanowi zapis szczególnie głęboki, jaki dzieje zbawienia na polskiej ziemi zwiazaty z data 1079 r. Jest to zapis wiary, nadziei i miłości, które nadaja właściwy $i$ pełny wymiar $\dot{z} y c i u$ czlowieka $i$ spoleczeństwa. Jest to zapis męstwa $i$ odwagi wyznania prawdy, która stanowi o szlachectwie ludzkiego ducha. Jest to zapis troski o zbawienie, o dobro duchowe $i$ doczesne bliźnich, rodaków $i$ wszystkich, którym służyć należy z nieustająca wytrwałościa. Jest to zarazem zapis wolności, która wyraża się $w$ tej właśnie stużbie $i$ oddaniu z miłości. Jest to owa przedziwna tradycja zjednoczenia i jedności, do którejjak świadczy historia - przyczynit się $w$ dziejach Narodu Polskiego św. Stanisław, Jego Smierć, Jego kult, w szczególności Jego kanonizacja.

Kościół w Polsce co roku odczytuje ten zapis. Co roku powraca do tej wielkiej stanisławowskiej tradycji, która stała się szczególnym dziedzictwem polskiego ducha. W Roku Pańskim 1979 pragnie do niej powrócić $w$ niezwykłych okolicznościach. Pragnie ja podjać szczególnie głęboko. Pragnie $z$ niej wyciagnać wnioski na życie codzienne. Znaleźc oparcie $w$ zmaganiu się ze słabościami, wadami, grzechami, które w sposób szczególny zagrażaja dobru Polaków i Polski. Pragnie znaleźć nowe oparcie dla nadziei $i$ wiary $w$ przyszłość swego posłannictwa $i$ swej postugi dla zbawienia każdego $i$ wszystkich.

$Z$ tymi pragnieniami, $z$ tymi żarliwymi wołaniami serc, jakie dochodza 
do mnie $z$ Ojczyzny, ja Jan Paweł II papież - syn ziemi polskiej tacze się caiym moim sercem $i z$ duszy przepetnionej wielkościa tego jubileuszu błogosławię.

W Rzymie, u św. Piotra, dnia 8 maja 1979 r., w pierwszym roku mojego pontyfikatu.

Jan Pawez PP. II 